\title{
Development of kefir from non-traditional raw materials enriched with blackberry products
}

\author{
Alexey Belyaev ${ }^{1, *}$, Vladimir Mosyagin², Galina Ryzhkova ${ }^{2}$, and Olga Shvets² \\ ${ }^{1}$ South-West State University, 94, 50 Let Oktyabrya str., Kursk, 305040, Russian Federation \\ ${ }^{2}$ Kursk State Agricultural Academy named after I. I. Ivanov, 70, Karl Marx Street, Kursk, 305021, Russian Federation
}

\begin{abstract}
The article presents data on the development of a new fermented milk product - kefir from unconventional milk raw materials of goat's milk and with the addition of blackberry vegetable additive. It is scientifically justified to use blackberry puree in the production technology, as well as the use of an unconventional type of milk for the manufacture of kefir. The influence of blackberries on the quality indicators of the developed kefir was also investigated. Comparative analysis of kefir with different concentrations of blackberries was carried out. According to the results of organoleptic evaluation, it was revealed that the consistency in all samples is uniform, without disturbing the clot. The taste is sour milk, slightly sharp, without extraneous flavors and odors. There is a good slightly sweet blackberry taste and smell with an increase in the concentration of the additive. It can also be noted from the results that kefir with blackberries is enriched with iron and other micro and macro elements in the comparison with the control sample. According to physicochemical indicators, the sample with $10 \%$ replacement of milk with mashed potatoes was identified as the closest to the control. The benefit of goat's milk kefir is due to the presence of various substances necessary for life. The properties of raw materials used are preserved and even enhanced considering the use of fermentation. Such kefir has a lot of natural proteins, the product is easily digested and absorbed by the body. Goat's kefir makes it possible to improve digestion and metabolic processes in regular consumption. This product reduces the risk of developing most intestinal infections because of rich composition. There are probiotics in such kefir that oppose the spread of harmful microflora in the intestine. The product includes potassium and magnesium - minerals that are especially important for normal operation of heart and vessels. There is phosphorus and calcium in it. The joint action of these minerals activates the process of regeneration and strengthening of bone tissue.
\end{abstract}

\section{Introduction}

Goat's milk is a successful alternative for feeding children with allergies to cow's milk proteins.

In world practice, there is also a tendency to use goat milk instead of cow milk to produce baby food, since it is believed that goat milk is more similar in structure to female milk.

If an adult or child has disturbed normal balance of intestinal microflora, fermented milk products from goat's milk, it will help to bring the intestine back to normal very quickly. Due to its composition, this milk strengthens immune system, gives strength for the human body to fight diseases [1]. Protein and vitamins A and B, contained in goat's milk, have beneficial effect on the development of the body.

An especially important characteristic of goat's milk is the presence of vitamin V12 in it. This vitamin is exceedingly rare in food, but it is important for the body, especially for children. This vitamin is responsible for hematopoiesis and controls metabolic processes [2]. Goat milk and goat milk products are useful because they contain a huge amount of calcium, and it is absorbed by the body by $97 \%$.

Low digestibility of calcium is associated with the difficulty of assimilating large molecules of cow's milk fat, with which it is directly associated. Calcium is absorbed from goat milk significantly more than $58-60 \%$ of the total content in the product [3]. Another the most important characteristics of goat's milk is low allergenicity. It contains biologically active substances that are not in cow's milk.

Biological value of goat's milk is supplemented by the fact that it contributes to the creation of an acidic environment in the intestine, due to which it suppresses the development of rotten microflora. Therefore, milk and dairy products are widely used for therapeutic purposes in intoxication with poisonous products of rotten microflora [4]. Lack of vitamins and minerals in the diet leads to metabolic disorders, performance decrement, rapid fatigue, and even various diseases.

Combining animal and plant raw materials is one way to correct nutritional pattern. Various publications describe the use of plant raw materials in fermented milk products such as kefir and yogurt. A study of French 
willow leaves use in the technology of cow's milk kefir showed its positive effect in the manufacture of kefir. Effect of added additive on fatty acid composition is described [5]. Other researchers also studied an antioxidant activity of yogurts and kefir from various unconventional types of milk. An antioxidant activity of these goat's milk products was effective [6]. Effectiveness of using goat's milk component in composing with fructooligosaccharides to produce kefirs with probiotic properties [7] was proved by the studies conducted by the authors. Lack of vitamins and minerals in the diet leads to metabolic disorders, performance decrement, rapid fatigue, and even various diseases.

Combining raw materials of animal and plant origin is one of the methods of correcting diets. Blackberry is available and relatively inexpensive sources of plant raw materials and most used in food technology [8]. The combination of dairy base with plant additives is a promising direction, since the requirements of functional nutrition are best met by multicomponent products based on animal and plant raw materials [9]. D. I. Akhtyamova, I. S. Bushueva developed a method for enriching kefir from goat's milk with biologically active substances for infant body using starter on kefir fungi. "Kumelact» was used as biologically active additive. This is a composition of natural biologically active substances obtained by combination of lactulose concentrate, honey extract of sprouted pumpkin seeds and malic acid [10]. The possibility of using wild-growing raw materials in the technology of fermented milk products is also described. Thus, the use of European mountain ash and black chokeberry in the technology of yoghurts made it possible to obtain new products with good organoleptic properties, and these plant additives contributed to the improvement of element composition. The amount of iron in samples increased [11]. G. G. Nigmetzyanova, L. Z Gabdukaeva describe the relevance of fruit and berry fillers use in dairy products production. The composition and properties of fruits and berries used as fillers, their influence on structural-mechanical, rheological, and organoleptic indices of various dairy products are also studied. The study confirmed that the use of fruit and berry fillers in the production of dairy products is a promising direction for expanding the range of products of this segment. The use of plant raw materials allows not only to expand the range, but also to improve the properties, biological value of dairy products, due to the increased content of valuable components in them $[12,13]$. It has been found that blackberries contain a significant amount of polyphenols represented by chlorogenic acid, catechins, leucoanthocyanides and anthocyanins. Anthocyanins predominate from flavonoids [14]. The use of blackberry puree eliminates the introduction of dyes, flavors, stabilizers, sweeteners due to the saturated aroma, bactericidal properties, providing the functions of the above ingredients in the production of kefir, leads to a decrease in the level of development of conditionally pathogenic microflora during storage, because of which sell-by-date is increased.

\section{Materials and methods}

The key stage in the production of kefir is fermentation of milk. Processes which form the main properties of finished product, in particular, lactic acid, alcoholic fermentation of lactose and gelation are carried out at this stage [15].

The following products were used to make test samples: goat milk $4.0 \%$ fat; starter on kefir fungi; pureed blackberries.

Fermentation of goat milk for 10-12 hours at a temperature of $22 \pm 2{ }^{\circ} \mathrm{C}$ is necessary for production technology of kefir control sample. Such fermentation consists of the following operations: maintaining temperature, adding starter prepared on kefir fungi, holding for 10-12 hours, cooling to $14 \pm 2{ }^{\circ} \mathrm{C}$ and mixing after 60-90 minutes after the start of cooling for 10-30 minutes [16].

To prepare three samples of kefir enriched with blackberries, before adding starter, milk is partially replaced with blackberries in 5.10.15\% ratio, kept for 10 12 hours, cooled to $14 \pm 2^{\circ} \mathrm{C}$ and mixed after $60-90$ minutes after cooling for 10-30 minutes.

Properties and quality of kefir are due to the development of starter microflora and the observance of production temperature regimes, as well as microbiological and biochemical processes that occur during the ripening of milk, maturating and storage of kefir. Therefore, special attention is paid to observance of temperature regimes and control over starter production on kefir fungi $[17,18]$.

A control sample prepared according to classic formulation and three prototypes were obtained with $5.10 .15 \%$ replacement of milk with blackberry puree.

Comparative analysis of organoleptic, physicochemical, and microbiological indices of produced samples was carried out to determine kefir enrichment efficiency.

Organoleptic evaluation of fermented milk products determines their appearance, consistency, color, taste, and smell. Physicochemical indices such as mass fraction of fat, $\%$; mass fraction, $\%$; mass concentration of calcium, $\mathrm{mg} / 100 \mathrm{~g}$ and acidity, ${ }^{\circ} \mathrm{T}$ were defined.

Peroxidase is not allowed in the product. The content of toxic elements, antibiotics, mycotoxins, pesticides, melamine, dioxins, and radionuclides in the product should not exceed the norms established by the laws or regulations of the states that have adopted the standard that do not contradict the requirements.

Standard document GOST 32925-2014 "Kefir for baby food. Specification "[19]. Weight fraction of protein was determined by measuring weight fraction of total nitrogen by Kjeldahl.

Determination of weight fraction of fat in kefir. 11 $\mathrm{g}$ of liquid product is weighed in two milk butyrometers, trying not to wet the neck, $10 \mathrm{~cm} 3$ of sulfuric acid is poured with a density of 1750 to $1770 \mathrm{~kg} / \mathrm{m}$ and $1 \mathrm{~cm} 3$ of isoamyl alcohol. The level of the mixture in butyrometer is set 1-2 mm below the base of the neck of butyrometer and it is allowed to add several drops of distilled water. Butyrometers are covered with dry plugs, introducing them slightly more than half into the neck of the 
butyrometer. Butyrometers are shaken until the protein substances are completely dissolved, turning them at least 5 times so that the liquids in them are completely mixed. It is recommended to apply chalk on the surface of the plugs for butyrometers. Install butyrometers with a plug down into a water bath at temperature $(65 \pm 2)^{\circ} \mathrm{C}$ and hold for 5 minutes. In this case, water level in the bath should be slightly higher than the level of the mixture in butyrometer. After removing butyrometers from the bath, they are inserted into centrifugal cups with a graduated part to the center. Butyrometers are centrifuged for $5 \mathrm{~min}$ at frequency $1000-1200 \mathrm{rpm}$. Each butyrometer is removed from the centrifuge and fat column is adjusted by the movement of a rubber plug so that it is in the graduated part of the butyrometer. Butyrometers are immersed with plugs down into a water bath at temperature $(65 \pm 2)^{\circ} \mathrm{C}$ and held for 5 minutes.

Butyrometers are taken out from one of the water baths and fat is counted quickly.

Determination of acidity. $10 \mathrm{~cm}^{3}$ of milk or liquid product and $20 \mathrm{~cm} 3$ of distilled water are added to 250 $\mathrm{cm}^{3}$ flask. Then 3 drops of phenolphthalein are added. In the analysis of fermented milk products, pipette is washed 3-4 times with the obtained mixture. The mixture is thoroughly mixed and titrated with a solution of sodium hydroxide $0,1 \mathrm{~N}$ until a weakly pink color of the solution does not disappear for 1 minute. Acidity in Turner degrees is found according to the following formula:

$$
T=V \cdot K
$$

where $\mathrm{V}$ - volume of sodium hydroxide solution spent on neutralization, $\mathrm{cm}^{3} ; \mathrm{K}$ - coefficient equal to 10 for milk, liquid, and reconstituted dry dairy products of baby food.

The presence of peroxidase is determined by adding hydrogen peroxide and iodide potassium starch to kefir. The method is based on the decomposition of hydrogen peroxide by enzyme peroxidase contained in milk and dairy products. Hydrogen peroxide decomposable active oxygen oxidizes potassium iodide, freeing iodine, which forms a blue compound with starch.

In the absence of peroxidase enzyme, the color of kefir in the test tube will not change, therefore, the milk used to produce kefir was pasteurized at a temperature above $75^{\circ} \mathrm{C}$. In the presence of peroxidase, kefir is dark blue.

\section{Results and Discussion}

The following samples were made to make it possible to use blackberries in the manufacture of sour milk products:

- control sample;

- $\quad$ kefir with the addition of blackberries (5\%);

- $\quad$ kefir with the addition of blackberries $(10 \%)$;

- kefir with the addition of blackberries (15\%).

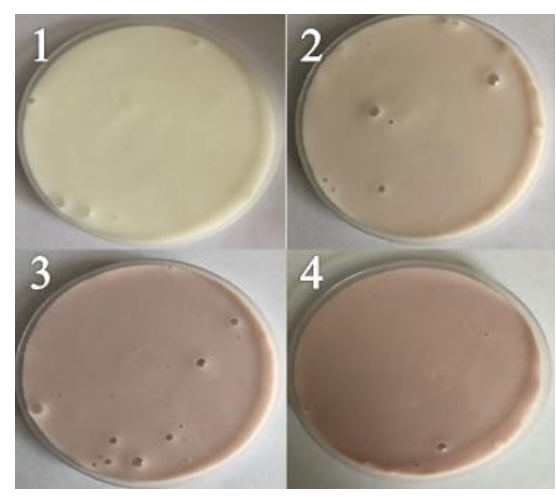

Fig. 1. Model kefir samples: 1- comparison sample, without adding blackberry puree; 2 - with $5 \%$ addition; 3 - with $10 \%$ addition; 4 - with $15 \%$ addition

To improve quality, different concentrations of blackberry puree were added to kefir. The formulation is shown in Table 1.

Table 1. Kefir formulation

\begin{tabular}{|c|c|c|c|}
\hline & $\begin{array}{c}\text { Full-fat } \\
\text { goat's } \\
\text { milk } \\
3,9 \% \text { fat, } \\
\text { Ml }\end{array}$ & $\begin{array}{c}\text { Ferment, } \\
\text { Ml }\end{array}$ & $\begin{array}{c}\text { Blackberry, } \\
\%\end{array}$ \\
\hline Control & 305 & 5,0 & - \\
\hline Sample №1 & 289,8 & 5,0 & 5 \\
\hline Sample №2 & 274,5 & 5,0 & 10 \\
\hline Sample №3 & 259,3 & 5,0 & 15 \\
\hline
\end{tabular}

The study of described above samples was carried out according to organoleptic, physicochemical parameters. Obtained kefir samples with the addition of blackberry puree during kefir digestion were later used to determine qualitative indicators. Organoleptic evaluation of kefir samples with the addition of blackberry puree at various concentrations determined the most promising samples. Consistency, taste, smell, and color were evaluated.

Table 2. Organoleptic indices of control samples

\begin{tabular}{|c|c|}
\hline Name & Control sample \\
\hline Consistence & $\begin{array}{c}\text { Uniform, with undisturbed } \\
\text { clot. Small gassiness } \\
\text { presented }\end{array}$ \\
\hline Taste and smell & $\begin{array}{c}\text { Sour milk, slightly sharp, } \\
\text { without extraneous tastes and } \\
\text { smells. }\end{array}$ \\
\hline Colour & Milky-white \\
\hline
\end{tabular}

Table 3. Organoleptic indices of control samples

\begin{tabular}{|c|c|c|c|}
\hline Name & Sample №1 & $\begin{array}{c}\text { Sample } \\
\text { №2 }\end{array}$ & Sample №3 \\
\hline
\end{tabular}




\begin{tabular}{|c|c|c|c|}
\hline $\begin{array}{c}\text { Consistenc } \\
\mathrm{e}\end{array}$ & $\begin{array}{c}\text { Uniform, } \\
\text { with } \\
\text { undisturbed } \\
\text { clot. Small } \\
\text { gassiness } \\
\text { presented }\end{array}$ & $\begin{array}{c}\text { Uniform, } \\
\text { with } \\
\text { undisturbe } \\
\mathrm{d} \\
\text { clot. Small } \\
\text { gassiness } \\
\text { presented }\end{array}$ & $\begin{array}{c}\text { Uniform, } \\
\text { with } \\
\text { undisturbed } \\
\text { clot. Small } \\
\text { gassiness } \\
\text { presented }\end{array}$ \\
\hline $\begin{array}{c}\text { Taste and } \\
\text { smell }\end{array}$ & $\begin{array}{c}\text { Sour milk, and } \\
\text { smell } \\
\text { slightly } \\
\text { sharp, } \\
\text { without } \\
\text { extraneous } \\
\text { tastes and } \\
\text { smells. } \\
\text { s to sour- } \\
\text { milk, there } \\
\text { is a slight } \\
\text { taste and } \\
\text { smell of } \\
\text { blackberrie } \\
\text { s }\end{array}$ & $\begin{array}{c}\text { Sour, } \\
\text { slightly } \\
\text { sweet, there } \\
\text { is a } \\
\text { significant } \\
\text { taste and } \\
\text { smell of } \\
\text { blackberries }\end{array}$ \\
& $\begin{array}{c}\text { Milky } \\
\text { colour } \\
\text { a slight } \\
\text { aink tint }\end{array}$ & $\begin{array}{c}\text { Light } \\
\text { purple tint }\end{array}$ & Purple \\
\hline
\end{tabular}

Physical and chemical parameters of samples are described in Table 4

Table 4. Physicochemical indices of control kefir sample

\begin{tabular}{|c|c|}
\hline Name & Control sample \\
\hline $\begin{array}{c}\text { Fat weight } \\
\text { fraction. } \%\end{array}$ & 3,8 \\
\hline $\begin{array}{c}\text { Protein weight } \\
\text { fraction. } \%\end{array}$ & 3,0 \\
\hline Acidity, ${ }^{0} \mathrm{~T}$ & 76 \\
\hline Peroxidases & no \\
\hline
\end{tabular}

Table 5. Physicochemical indices of kefir prototypes

\begin{tabular}{|c|c|c|c|}
\hline Name & $\begin{array}{c}\text { Sample } \\
\text { №1 }\end{array}$ & $\begin{array}{c}\text { Sample } \\
\text { №2 }\end{array}$ & Sample №3 \\
\hline $\begin{array}{c}\text { Fat weight } \\
\text { fraction. \% }\end{array}$ & 3,4 & 3,5 & 3,4 \\
\hline $\begin{array}{c}\text { Protein } \\
\text { weight } \\
\text { fraction. \% }\end{array}$ & 2,80 & 2,80 & 2,80 \\
\hline Acidity, ${ }^{0} \mathrm{~T}$ & 80 & 82 & 90 \\
\hline Peroxidases & No & No & No \\
\hline
\end{tabular}

The data of Table 4 indicate that physicochemical indicators correspond to GOST standard 32925-2014 "Kefir for baby food. Specifications" and TR CU 033/2013 Technical Regulations of Custom Union "On safety of milk and dairy products".

Introduction of blackberries contributed to the improvement of organoleptic and physicochemical indicators. A sample with the addition of blackberries in an amount of $10 \%$ has more tender taste, with nice color and physicochemical indicators are close to indices in control sample.

A spectrophotometric concentration method was used to determine concentration of iron mineral element. Genesys 10S UV-Vis spectrophotometer was used. Iron was determined in kefir samples. Samples were burned at "Temos Express" before determination. Method of iron determining is based on measuring optical density of the solution of the complex compound of bivalent iron with red orthophenanthrolin.

Weight fraction of iron in products $(\mathrm{X})$ in $\mathrm{mln}^{-1}$ $(\mathrm{mg} / \mathrm{kg})$ was calculated by the following formula:

$$
X=\left(m \_1 \times V\right) /\left(V \_1 \times m\right),
$$

where $m_{1}$ is the weight of iron found from the calibration schedule, mgk; $\mathrm{V}$ - total volume of mineralizate solution, $\mathrm{cm}^{3} ; \mathrm{V}_{1}$ - volume of mineralizate solution taken for determination, $\mathrm{cm}^{3} ; \mathrm{m}$ - weight of product suspension taken for mineralization, $\mathrm{g}$;

The results of iron determination in the obtained samples are shown in Table 6.

Table 6. Iron content of test samples

\begin{tabular}{|c|c|c|c|}
\hline Control & $\begin{array}{c}\text { Sample } \\
\text { №1 }\end{array}$ & $\begin{array}{c}\text { Sample } \\
\text { №2 }\end{array}$ & Sample №3 \\
\hline 0,098 мг/кг & $\begin{array}{c}0,138 \\
\text { мг/кг }\end{array}$ & $\begin{array}{c}0,190 \\
\text { мГ/кг }\end{array}$ & 0,238 мГ/кг \\
\hline
\end{tabular}

Analysis of prototypes showed that when blackberries are added to kefir, iron content increases, which makes kefir more useful.

\section{Conclusion}

Obtained data on the research carried out on the development of goat's milk kefir with the addition of blackberry products show that according to the results of organoleptic assessment, the best sample is with $10 \%$ blackberry puree. The results of physicochemical studies determined that the introduction of blackberries in the process of kefir preparing increases its acidity. Acidity increases with increasing percentage of blackberry puree at the stage of fermentation.

Weight fraction of fat and protein in the prototypes decreases slightly, which may be due to the replacement of part of milk with blackberry puree. Physicochemical indicators correspond to GOST standard 32925-2014 "Kefir for baby food. Specifications. " The amount of iron in the samples also increases as the percentage of blackberry application increases. The introduction of blackberry contributed to the improvement of quality indicators.

\section{References}

1. N.Yu. Alekseeva, V.P. Aristova, A.P. Patratiy and others Milk composition as raw materials for dairy industry(Agropromizdat, Moscow, 1986)

2. A.A. Ivonina Expert Goat's milk and allergy 115 (2003) 
3. M.G. Baranova, D.M. Ostashevskaya, JI.B. Krasnikova J. Dairy industry Chemical composition of fermented milk products from goat's milk 218 (1998)

4. G.S. Korobkin Baby food. Research and technology (Food industry, Moscow, 1970)

5. A G Belyaev et al Research of the effect of willowherb products in the preparation of kefir on the composition of fatty acids (IOP Conf. Ser.: Earth Environ. Sci. 640 042006, 2021)

6. M. Baniasadi, M. Azizkhani, PEJ Saris et al. J Food Sci Technol Comparative antioxidant potential of kefir and yoghurt of cattle and not cattle (2021)

7. İ. Buran, C. Akal, S. Ozturkoglu-Budak, A. Yetisemiyen LWT Rheological, sensorial and volatile profiles of synbiotic kefirs produced from cow and goat milk containing varied probiotics in combination with fructooligosaccharide 148 (2021)

8. A.Yu. Zolotin, S.V. Felik, S.V. Simonenko, T.A. Antipova, N.V. Lavrova, E.V. Lysenko Reports of TSHA. Collection of scientific and practical conferences of the Timiryazev Academy On the development of baby foods on milky basis with fruitberry and vegetable fillers 277 (Moscow, 2009)

9. V.D. Kharitonov, I.V. Rozhkova, V.F. Semenikhina, I.A. Makeeva Dairy industry What product should be called kefir 457 (2010)

10. I. S. Bushuev, D. I. Akhtyamova Bull. of Kazan Tech. Univ. Rationale for the use of biologically active and nutritional additives in the technology for the production of children's kefir from goat's milk 20(21) 158 (2017)

11. A.G. Belyaev, S.G. Boev, N.S. Baroyan Studying the possibility of using ordinary mountain ash and chokeberry in the manufacture of yogurt Tech. of the food and proc. industry AIC-healthy food prod. 415 (2019)

12. G. G. Nigmetzyanova, L. Z Gabdukaeva Modern technologies: current issues, achievements and innovations: collection of articles of the XIII ISPC in $2 \mathrm{~h} .1$ The use of natural fruit and berry fillers in the technology of dairy products 34 (Penza, 2018)

13. V.I. Lebedkov et al. applicant and patent holder of Ufamolagroprom JSC Method of preparing kefir with healthy additive (Patent RU 2155488, №98118585/13, declared. 12.10.1998, publ. 10.09.2000)

14. L.B. Golubeva, A.N. Ponomarev, K.K. Polyansky Modern technologies of pasteurized milk (Voronezh, Publishing House of Voronezh State University, 2001)

15. S.F. Apolokhova Development of biotechnology of integrated processing of goat's milk for application in pharmaceutical, cosmetic and food industries: Autoref. diss. edging. biol. sciences (Stavropol, 2002)

16. E.A. Purgina, A.I. Khodos, A.B. Kiriyenko, Dakhnovich A.A. Youth and science Performance indicators of the enterprise 187 (2014)

17. N.G. Alekseev, T.A. Kudryavtseva, L.A. Zabodalova, T.N. Evstigneeva Baby food technology (Kolos, Moscow, 1992)
18. S.F. Andrusenko, S.M. Kunizhev Milk processing Directions of goat milk use 1 54(2004)

19. GOST 32925-2014 Kefir for baby food. Specifications (Standardinform, Moscow, 2015) 